Volume 1 Nomor 1 Mei 2021: Halaman: $13-21$

Doi: 10.47650/pjphsr.v1i1.208

ISSN : 2777-1296

OJS: http://journal.unpacti.ac.id/index.php/pjphsr

\title{
RISK FACTORS FOR DENGUE HEMORRHAGIC FEVER (DHF) CASES IN THE WORKING AREA OF MAMAJANG HEALTH CENTER, MAKASSAR CITY
}

\section{Faktor Risiko Kejadian Demam Berdarah Dengue (DBD) di Wilayah Kerja Puskesmas Mamajang Kota Makassar}

\section{Kornelia Fini", Nur Hamdani Nur, Muharti Syamsul}

Prodi Kesehatan Masyarakat, Fakultas Kesehatan Masyarakat, Universitas Pancasakti, Makassar

*Alamat Korespondensi: korneliafini2@gmail.com

\section{Article Info}

Article History

Received: 15 Mei 2021

Revised : 21 Mei 2021

Accepted : 25 Mei 2021

\section{Keywords :}

DHF, the use of mosquito nets, the use of gauze, hanging clothes, the presence of useditems

\begin{abstract}
ABSTRAK
Dengue Hemorrhagic Fever (DHF) is a major public health problem in the world. Where since 1968 the cases tended to increase and its distribution was getting larger. The occurrence of DHF cases in the working area of Mamajang Health Center is due to the fact that some respondents in this study do not use a mosquito net with gauze, have a habit to hang clothes, and do not remove used items around their house. This study aims to determine the risk factors for the incidence of Dengue Hemorrhagic Fever (DHF) in the working area of Mamajang Health Center, Makassar City. The type of this study was an analytic observational using a case-control design. Samples in this study consisted of 72 respondents of which 24 people were included in the case class while 48 people were in the control class. The samples in this study were selected by using the purposive sampling technique. The data were obtained from the survey using a questionnaire. There was a relationship between the habit of using a mosquito net and DHF cases ( $p$-value $=0.032$ : $O R=5,000) ;$ there was a relationship between the use of gauze and DHF cases ( $p$-value = 0.010: $O R=0265)$; there was a relationship between the habit of hanging clothes and DHF cases ( $p$-value $=0.008: O R=0,252$ ), and there was no relationship between the presence of used items and DHF cases ( $p$-value $=0.256: O R=0,234)$. Community participation is expected with concerns environment and behavior to minimize the incidence of DHF.
\end{abstract}

Penyakit Demam Berdarah Dengue (DBD) merupakan salah satu masalah kesehatan masyarakat yang utama di dunia. Sejak tahun 1968 jumlah kasusnya cenderung meningkat dan penyebarannya bertambah luas. Penelitian ini bertujuan untuk mengetahui faktor risiko kejadian DBD di Wilayah Kerja Puskesmas Mamajang Kota Makassar. Jenis penelitian yang digunakan adalah analitik observasional dengan desain "Case Control". Jumlah sampel adalah 72 responden dengan 24 kasus dan 48 kontrol. Sampel dalam penelitian ini diambil dengan teknik purposive sampling. Data diperoleh dari hasil survei dengan menggunakan kuesioner dan dianalisis menggunakan uji chisquare. Hasil penelitian menunjukkan bahwa ada hubungan antara kebiasaan menggunakan kelambu dengan kejadian DBD (nilai $p$-value $=0,032 ; O R=5,000$ ), ada hubungan dengan penggunaan kawat kasa dengan kejadian DBD ( $p$-value $=0,010$; $\mathrm{OR}=0,265)$, ada hubungan antara kebiasaan menggantung pakaian dengan kejadian DBD ( $p$-value $=0,008 ; \mathrm{OR}=0,252$ ), dan tidak ada hubungan antara keberadaan barang bekas di sekitar rumah dengan kejadian DBD ( $p$-value=0,256; OR=0,234). Peran serta masyarakat diharapkan dengan peduli lingkungan dan perilaku untuk meminimalisir kejadian DBD. 


\section{PENDAHULUAN}

Penyakit Demam Berdarah Dengue (DBD) merupakan salah satu penyakit menular yang disebabkan oleh virus dengue yang ditularkan dari satu orang keorang lain melalui gigitan nyamuk Aedes aegypti dan Aedes albopictus. Nyamuk tersebut hampir terdapat diseluruh pelosok Indonesia. Selain itu, kedua nyamuk tersebut juga akan meningkat pesat saat musim hujan (Rahmawati, 2016). Menurut Tosepu R (2016), demam berdarah dengue (DBD) adalah penyakit demam akut yang sering ditemukan didaerah tropis dengan penyebaran geografis yang mirip dengan malaria. Penyakit ini disebabkan oleh salah satu dari 4 serotipe virus dari genus Flavivirus, famili Flafifiridae. Setiap serotipe cukup berbeda sehingga tidak ada waba dan proteksi silang yang disebabkan oleh beberapa serotipe (hiperendemistas) dapat terjadi. Demam berdarah disebarkan kepada manusia oleh nyamuk Aedes aegypti.

Kasus DBD pertama kali terjadi pada tahun 1953 di Negara Filipina, disusul Negara Thailand dan Vietnam. Pada tahun 1970 hanya 9 negara yang mengalami wabah $\mathrm{DBD}$, namun penyakit $\mathrm{DBD}$ sekarang telah menjadi endemik pada 100 negara salah satunya adalah Negara Indonesia. WHO mencatat indonesia merupakan negara dengan kasus tertinggi di Asia Tenggara (Wijirahayu,2019). Penyakit DBD pada mulanya ditemukan di Surabaya dan Jakata tahun 1968 dengan kematian sebanyak 24 orang, selanjutnya akan menyebar kebeberapa provinsi di Indonesia (Anwar, 2015). Penyakit DBD akan berpengaruh terhadap perubahan iklim termasuk lingkungan fisik, Perubahan iklim akan berpengaru terhadap media transmisi penyakit, karena vektor akan berkembangbiak optimum apabila suhu, kecepatan angin,dan kelembapan tersedia dalam jumlah yang optimum untuk kehidupannya (Wulandari ,2016 dalam Sunarya ,2019).

Menurut data World Health Organization (WHO), di Kamboja angka kasus DBD dari Bulan Januari hingga Mei 2016 sebanyak 1.771 dengan jumlah kematian sebanyak 4 orang, kemudian tahun 2017 kasus DBD meningkat menjadi 3.130 kasus, sedangkan tahun 2018 jumlah total kasus DBD sebanyak 9.122 kasus yang telah dilaporkan. Selain itu di Singapura, kasus DBD juga mengalami peningkatan. Pada tahun 2017 terdapat 2.615 kasus DBD sedangka Pada tahun 2018 jumlah penderita DBD yang dilaporkan sebanyak 2.873 kasus (Wijirahayu, 2019)

Menurut data Kemenkes RI, di Indonesia pada tahun 2016 dalam (Sari,2019) terdapat jumlah kasus DBD sebanyak 204.171 kasus dengan jumlah kematian sebanyak 1.598 orang. Pada tahun 2016 jumlah kasus DBD mengalami peningkatan dibandingkan pada tahun 2015 sejumlah 129.650 kasus. Jumlah kematian akibat DBD tahun 2016 juga meningkat dari tahun 2015 dengan jumlah 1.071 orang. Angka kesakitan DBD tahun 2016 juga meningkat dari tahun 2015, yaitu 50,75 menjadi 78,85 per 100.000 penduduk. Namun, Case Fatality Rate (CFR) mengalami penurunan dari 0,83\% tahun 2015 menjadi 0,75\% tahun 2016. Kasus DBD di Indonesia Tahun 2017 mengalami penurunan dengan jumlah 59.047 kasus dan jumlah kematian sebanyak 444 orang.

Kejadian DBD di Sulawesi Selatan selalu meningkat dalam beberapa tahun terakhir. Pada tahun 2014 dengan jumlah kasus DBD sebanyak 2.996 kasus dengan jumlah kematian sebanyak 30 orang serta CFR (case fatality rate) $0,84 \%$. Tahun 2015 jumlah kasus menjadi 4.818 kasus dengan jumlah kematian 30 orang serta CFR $0,62 \%$. Sama halnya pada tahun 2016 meningkat dari tahun sebelumnya menjadi 7.568 kasus dengan jumlah kematian 48 orang serta CFR $0,63 \%$ (Maralia, 2018).

Data kasus Demam Berdarah Dengue yang diperoleh peneliti dari Puskesmas Mamajang Kota Makassar angka kejadian DBD dalam 3 tahun terakhir yaitu: tahun 2017 tercatat sebanyak 17 kasus dengan tidak ada kematian, tahun 2018 jumlah penderita DBD sebanyak 14 kasus dengan tidak ada kematian, sedangkan pada tahun 2019 jumlah penderita DBD yang dilaporkan mengalami penurunan sebanyak 9 kasus dan tidak ada 
kematian. (Profil Puskesmas Mamajang Kota Makassar, 2020).

Penelitian ini dilakukan untuk mengetahui faktor risiko kejadian DBD di wilayah Kerja Puskesmas Mamajang Kota Makassar.

\section{BAHAN DAN METODE}

Jenis peneliti ini merupakan jenis penelitian kuantitatif dengan metode survei analitik dan menggunakan desain case control yaitu suatu rancangan penelitian yang membandingkan antara kelompok kasus dengan kelompok kontrol untuk mengetahui proporsi kejadian berdasarkan riwayat ada tidaknya paparan. Penelitian ini dilaksanakan di wilayah Kerja Puskesmas Mamajang Kota Makassar. Subyek yang digunakan sebanyak 72 sampel dengan perbandingan kasus kontrol adalah 24 kasus dan 48 kontrol. pengambilan sampel menggunakan purposive sampling. Untuk pengambilan sampel kasus diperoleh dari data Puskesmas Mamajang untuk bulan Agustus 2019 sampai Agustus 2020 dan tercatat pada data rekam medis Puskesmas Mamajang.

Pengumpulan data diperoleh melalui wawancara yang dilakukan secara langsung kepada responden dengan menggunakan lembar koesioner yang telah disusun dan melakukan observasi langsung kepada responden di Wilayah Kerja Puskesmas Mamajang. Dalam menganalisis data peneliti menggunakan Analisis univariat untuk mendapatkan gambaran umum variabel dalam bentuk tabel dan menggunakan Analisis bivariat dengan uji Chi square dan uji Fisher's Exact Test untuk mengetahui hubungan yang signifikan antara variabel bebas dengan variabel terikat, analisis data menggunakan bantuan program SPSS.

\section{HASIL}

Karakteristik responden diperoleh pada penelitian ini sebagaimana tabel 1 , yaitu: Umur responden bervariasi mulai dari umur 18 tahun hingga umur 60 tahun dimana persentase tertinggi pada umur 31-40 tahun sebanyak 24 responden (33,3\%). Berdasarkan jenis kelamin terlihat presentase responden lebih banyak pada jenis kelamin perempuan dengan jumlah 64 responden (88,9\%). Sedangkan berdasarkan tingkat pendidikan telihat bahwa persentase responden tertinggi yaitu SMA sebanyak 40 responden $(55,6 \%)$.

Tabel 1. Karakteristik Responden

\begin{tabular}{lcc}
\hline \multirow{2}{*}{ Karakteristik } & \multicolumn{2}{c}{ Responden } \\
\cline { 2 - 3 } & $\mathbf{n}$ & $\mathbf{\%}$ \\
\hline Umur & 1 & 1,4 \\
$18-20$ & 12 & 16,7 \\
$21-30$ & 24 & 33,3 \\
$31-40$ & 18 & 25,0 \\
$41-50$ & 17 & 23,6 \\
51-60 & & \\
Jenis Kelamin & 8 & 11,1 \\
Laki-laki & 64 & 88,9 \\
Perempuan & & \\
Pendidikan & 11 & 15,3 \\
SD & 12 & 16,7 \\
SMP & 40 & 55,6 \\
SMA & 9 & 12,5 \\
Sarjana & $\mathbf{7 2}$ & $\mathbf{1 0 0}$ \\
\hline Total & & \\
\hline
\end{tabular}

Dari 9 (100\%) responden yang menggunakan kelambu terdapat $6 \quad(66,7 \%)$ responden pada kelompok kasus dan $3(33,3 \%)$ responden pada kelompok kontrol. Sedangkan dari 63 (100\%) yang tidak menggunakan kelambu terdapat $8(28,6 \%)$ responden pada kelompok kasus dan pada kelompok kontrol $45(71,4 \%)$ responden. Hasil uji statistik dengan Fisher's Exact Test diperoleh nilai $p$-value $0,032<\alpha=0,05$ artinya ada hubungan antara kebiasaan menggunakan kelambu dengan kejadian DBD di wilayah kerja Puskesmas Mamajang. Dari nilai OR sebesar 5,000 yang artinya bahwa responden yang tidak menggunakan kelambu 5,000 kali lebih berisiko menderita DBD dibandingkan dengan responden yang memiliki kebiasan menggunakan kelambu (Tabel 2).

Dilihat dari penggunaan kawat kasa pada ventilasi rumah, diketahui bahwa dari 45 (100\%) yang menggunakan kawat kasa terdapat 10 $(22,2 \%)$ responden pada kelompok kasus dan 35 
$(77,8 \%)$ responden pada kelompok kontrol. Sedangkan dari 27 (100\%) yang tidak menggunakan kawat kasa terdapat 14 (51,9\%) responden pada kelompok kasus dan 13 (48,1\%) responden pada kelompok kontrol. Hasil uji statistik dengan Fisher's Exact Test yang sudah di peroleh nilai $p$-value $0.010<\alpha=0.05$ sehingga dapat disimpulkan bahwa ada hubungan dengan penggunaan kawat kasa dengan kejadian DBD diwilayah kerja Puskesmas Mamajang. Dari nilai OR sebesar 0,265 yang artinya bahwa responden yang tidak menggunakan kawat kasa 0,265 kali lebih berisiko menderita DBD dibandingkan dengan responden yang menggunakan kawat kasa (Tabel 2).

Dari 48 (100\%) responden yang memiliki kebiasaan menggantung pakaian terdapat 11 $(22,9 \%)$ responden pada kelompok kasus dan 37 $(77,1 \%)$ responden pada kelompok kontrol. Sedangkan dari 24 (100\%) yang tidak memiliki kebiasaan menggantung pakaian terdapat 13 $(54,2 \%)$ responden pada kelompok kasus dan 11 $(45,8 \%)$ responden pada kelompok kontrol. Hasil uji statistik dengan chi-square yang sudah di peroleh nilai $p$-value $0.008<\alpha=0.05$ artinya bahwa ada hubungan antara kebiasaan menggantung pakaian dengan kejadian DBD di wilayah kerja Puskesmas Mamajang. Berdasarkan nilai OR sebesar 0,252 yang artinya bahwa responden yang memiliki kebiasaan menggantung pakaian pada kelompok menderita 0,252 kali lebih berisiko menderita DBD dibandingkan dengan responden yang tidak memiliki kebiasaan menggantung pakaian (Tabel 2).

Sedangkan berdasarkan keberadaan barang bekas di sekitar rumah responden, dapat diketahui bahwa dari 69 (100\%) yang memiliki barang bekas di sekitar rumah terdapat 22 (31,9\%) responden pada kelompok kasus dan 47 (68,1\%) responden pada kelompok kontrol. Sedangkan dari $3(100 \%)$ yang tidak memiliki barang bekas disekitar rumah terdapat $2(66,7 \%)$ responden pada kelompok kasus dan $1(33,3 \%)$ responden pada kelompok kontrol. Hasil uji statistik dengan Fisher's Exact Test yang sudah diperoleh nilai $P$ value $0,256>\alpha=0.05$ artinya bahwa tidak ada hubungan antara keberadaan barang bekas di sekitar rumah dengan kejadian DBD di wilayah kerja Puskesmas Mamajang. Berdasarkan nilai OR sebesar 0,234 yang artinya bahwa responden yang di sekitar rumah tidak terdapat barang bekas pada kelompok tidak menderita 0,234 kali lebih berisiko menderita DBD dibandingkan dengan responden yang sekitar rumah terdapat barang bekas (Tabel 2).

\section{PEMBAHASAN}

\section{Hubungan kebiasaan menggunakan kelambu dengan kejadian DBD}

Kelambu merupakan tirai tipis, tembus pandang dengan jaringan-jaringan yang dapat menahan berbagai serangan nyamuk, dan serangga lainnya yang dapat menggigit atau mengganggu orang yang menggunakannya (Cinesa, 2016).

Sebagian masyarakat di daerah endemis DBD yang menganggap masalah penyakit DBD merupakan masalah biasa yang tidak perlu dikawatirkan dampaknya. Anggapan tersebut membuat mereka lengah dan kurang berkontribusi dalam upaya pencegahan dan pemberantasan DBD. Di indonesia, mendiagnosis, mengobati dan merawat sendiri bilah sakit DBD merupakan hal yang biasa (Pusdatin, 2013 dalam Cinesa, 2016).

Kebiasaan-kebiasaan masyarakat dengan lingkungan tempat tinggalnya, banyak aktifitas masyarakat yang membuat seseorang dapat dengan mudah kontak dengan nyamuk. Kebiasaan masyarakat tidak menggunakan kelambu pada pagi maupun sore hari akan mudah terkena DBD, karena kelambu dapat digunakan sebagai bahan untuk menghindari gigitan nyamuk (Cinesa, 2016).

Uji statistik dengan Fisher's Exact Test diperoleh nilai $P$-value $0,032<\alpha=0,05$ artinya ada hubungan antara kebiasaan menggunakan kelambu dengan kejadian DBD di wilayah kerja Puskesmas Mamajang. Dari nilai OR sebesar 5,000 yang artinya bahwa responden yang tidak menggunakan kelambu 5,000 kali lebih berisiko 
menderita DBD dibandingkan dengan responden yang memiliki kebiasan menggunakan kelambu.

Hasil penelitian ini sejalan dengan hasil penelitian Cinesa (2016) di Wilayah Kerja Puskesmas Elar yang menemukan ada hubungan yang bermakna antara penggunaan kelambu dengan kejadian $\mathrm{DBD}$, dengan nilai $p=0,002$. Hasil penelitian ini juga diperkuat dengan hasil penelitian Utomo (2017) mengenai hubungan antara perilaku pemberantasan sarang nyamuk dan kejadian demam berdarah dengue hasil uji Chi-square didapatkan p-value sebesar 0,018, yang artinya ada hubungan antara kebiasaan tidur menggunakan kelambu dengan kejadian Demam Berdarah Dengue di Desa Sojomerto, Reban, Batang.

Tabel 2. Hubungan antara Variabel Independen dengan Kejadian DBD di Wilayah Kerja Puskesmas Mamajang Kota Makassar

\begin{tabular}{|c|c|c|c|c|c|c|c|}
\hline \multirow{3}{*}{ Variabel } & \multicolumn{4}{|c|}{ Kejadian DBD } & \multirow{2}{*}{\multicolumn{2}{|c|}{ Total }} & \multirow{3}{*}{$\begin{array}{c}\text { p Value } \\
\text { (OR) }\end{array}$} \\
\hline & \multicolumn{2}{|c|}{ Ya } & \multicolumn{2}{|c|}{ Tidak } & & & \\
\hline & $\mathbf{n}$ & $\%$ & $\mathbf{n}$ & $\%$ & $\mathbf{n}$ & $\%$ & \\
\hline \multicolumn{7}{|l|}{ Penggunaan Kelambu } & \multirow{3}{*}{$\begin{array}{c}0,032 \\
(5,000)\end{array}$} \\
\hline $\mathrm{Ya}$ & 6 & 66,7 & 3 & 33,3 & 9 & 100 & \\
\hline Tidak & 18 & 28,6 & 45 & 71,4 & 63 & 100 & \\
\hline \multicolumn{7}{|l|}{ Penggunaan Kawat Kasa } & \multirow{3}{*}{$\begin{array}{c}0,010 \\
(0,265)\end{array}$} \\
\hline Ya & 10 & 22,2 & 35 & 77,8 & 45 & 100 & \\
\hline Tidak & 14 & 51,9 & 13 & 48,1 & 27 & 100 & \\
\hline \multicolumn{7}{|c|}{ Kebiasaan Menggantung Pakaian } & \multirow{3}{*}{$\begin{array}{c}0,008 \\
(0,252)\end{array}$} \\
\hline $\mathrm{Ya}$ & 11 & 22,9 & 37 & 77,1 & 48 & 100 & \\
\hline Tidak & 13 & 54,2 & 11 & 45,8 & 24 & 100 & \\
\hline \multicolumn{7}{|c|}{ Keberadaan Barang Bekas } & \multirow{3}{*}{$\begin{array}{c}0,256 \\
(0,234)\end{array}$} \\
\hline Ya & 22 & 31,9 & 47 & 68,1 & 69 & 100 & \\
\hline Tidak & 2 & 66,7 & 1 & 33,3 & 3 & 100 & \\
\hline
\end{tabular}

Sedangkan hasil penelitian ini berbeda dengan hasil penelitian Malau, Nurjazuli, dan Setiani, (2015) mengenai hubungan faktor lingkungan dan perilaku keluarga dalam pencegahan dengan kejadian demam berdarah dengue yang menyatakan tidak ada hubungan yang bermakna antara variabel penggunaan kelambu dengan kejadian Demam Berdarah Dengue di wilayah kerja Puskesmas Kedungmundu Kecamatan Tembalang Kota Semarang tahun 2014 dengan nilai $p$-value 0,060.

Hubungan penggunaan kawat kasa pada ventilasi rumah dengan kejadian DBD

Suatu bangunan atau rumah dengan kondisi ventilasi tidak terpasang kawat kasa akan memudahkan nyamuk untuk masuk ke dalam bangunan untuk menggigit manusia, beristirahat, dan mendapatkan tempat untuk berkembangbiak. Ventilasi yang dilengkapi dengan kawat kasa akan memperkecil kontak nyamuk dengan manusia di dalam ruangan karena nyamuk dari luar ruangan tidak dapat masuk ke dalam ruangan (Astuti, 2018).

Keberadaan ventilasi pada suatu bangunan selain untuk pencahayaan juga digunakan sebagai tempat pertukaran uda dan ventilasi dapat dimanfaatkan oleh vektor untuk keluar masuk ke dalam rumah. Kawat kasa merupakan salah satu alat pelindung yang terbuat dari besi yang dipasangkan pada ventilasi. Pemakaian kasa pada ventilasi yaitu sebagai salah satu upaya pencegahan penularan penyakit DBD yang mana penggunaan kasa ini bertujuan agar nyamuk tidak dapat masuk ke dalam rumah dan menggigit 
manusia. Selain penggunaan kasa pada ventilasi beberapa kebiasaan masyarakat dilapangan yang juga menjadi faktor penyebaran vektor DBD yaitu kebiasaan membuka pintu dan jendela di pagisiang hari. Adapun hal lainnya yang juga menjadi faktor penyebab terjadinya penyebaran penyakit DBD antara lain karena memiliki kebiasaan menggantung pakaian bekas pakai di dalam rumah.

Rumah dengan kondisi ventilasi tidak terpasang kasa nyamuk akan memudahkan nyamuk untuk masuk ke dalam rumah untuk menggigit manusia dan untuk beristirahat. Keadaan ventilasi rumah yang tidak ditutupi kawat kasa akan menyebabkan nyamuk masuk kedalam rumah. Dengan tidak adanya kasa nyamuk pada ventilasi rumah, akan memudahkan nyamuk Aedes masuk ke dalam rumah pada pagi hingga sore hari. Hal ini tentunya akan memudahkan terjadinya kontak antara penghuni rumah dengan nyamuk penular Demam Berdarah Dengue (DBD), sehingga akan meningkatkan risiko terjadinya penularan DBD yang lebih tinggi dibandingkan dengan rumah yang ventilasinya terpasang kasa. (Tamza, 2013).

Ventilasi dikatakan memenuhi syarat kesehatan bila pada lubang ventilasi terpasang jaring-jaring atau kawat kasa. Semakin banyak bagian ventilasi terpasang kawat kasa maka semakin kecil pula kepadatan vektor di dalam ruang. Ventilasi yang dilengkapi dengan kawat kasa akan memperkecil kontak nyamuk dengan manusia di dalam ruangan karena nyamuk dari luar ruangan tidak dapat masuk ke dalam ruangan (Astuty, 2018)

Hasil uji statistik dengan Fisher's Exact Test yang sudah di peroleh nilai $P$-value $0,010<\alpha=0.05$ sehingga dapat disimpulkan bahwa ada hubungan dengan penggunaan kawat kasa dengan kejadian DBD di Wilayah Kerja Puskesmas Mamajang. Dari nilai OR sebesar 0,265 yang artinya bahwa responden yang tidak menggunakan kawat kasa 0,265 kali lebih beresiko menderita DBD dibandingkan dengan responden yang menggunakan kawat kasa.
Hasil penelitian ini sejalan dengan hasil penelitian Utomo (2017) mengenai hubungan antara perilaku pemberantasan sarang nyamuk dan kejadian demam berdarah dengue dengan nilai $p$ value 0,05 yang artinya ada hubungan antara memasang kawat kasa dengan kejadian DBD di desa Sojomerto, Reban Batang.

Hasil penelitian ini juga diperkuat dengan hasil penelitian wijirahayu dan Sukesi (2019) mengenai hubungan kondisi lingkungan fisik dengan kejadian Demam Berdarah Dengue.Hasil uji statistik fisher diperoleh hasil analisis bivariat dengan nilai $p<0,05$ yaitu 0,039 yang artinya ada hubungan yang bermakna secara statistik antara variabel berkasa dengan kejadian DBD di Wilayah Kerja Puskesmas Kalasan Kabupaten Sleman Tahun 2018 dengan nilai OR=0,072. Namum berbeda dengan penelitian Sari dkk didapatkan nilai $p=0,330$ yang artinya tidak ada hubungan ventilasi berkasa dengan kejadian DBD di Semarang. .

\section{Hubungan kebiasaan menggantung pakaian dengan kejadian DBD}

Pakaian yang manggantung dalam ruangan merupakan tempat yang disenangi nyamuk Aedes untuk beristirahat setelah menghisap darah manusia. Setelah beristirahat pada saatnya akan menghisap darah manusia kembali sampai nyamuk tersebut cukup darah untuk pematangan sel telurnya. Jika nyamuk yang beristirahat pada pakaian menggantung tersebut menghisap darah penderita demam berdarah dan selanjutnya pindah dan menghisap darah orang yang sehat maka dapat tertular virus demam berdarah dengue (Widodo, 2002 dalam Yunita dkk,2012).

Responden yang sering menggantung pakaian memang merupakan perilaku berisiko menderita DBD karena nyamuk menyukai ruang yang lembab dan gelap yang biasanya diantara pakaian yang digantung tersebut. Hal ini karena pada umumnya masyarakat mengantung pakaian hanya dalam jangka waktu yang tidak terlalu lama. Kebiasaan menggantung pakaian ini sangat membudaya dalam masyarakat dan sangat sulit untuk dihapuskan Padahal kebiasaan ini sangat 
merugikan kesehatan khususnya yang berkaitan dengan kejadian DBD. Pakaian yang tergantung ditempat yang lembab dan sedikit angin sangat disukai nyamuk Aedes aegypti dan Ades albopictus untuk beristirahat, padahal biasanya orang menggantung pakaian ini di kamar tidur tempat untuk beristirahat.

Hasil uji statistik dengan chi-square yang sudah di peroleh nilai $P$ value $0.008<\alpha=0.05$ artinya bahwa ada hubungan antara kebiasaan menggantung pakaian dengan kejadian DBD di wilayah kerja Puskesmas Mamajang. Berdasarkan nilai OR sebesar 0,252 yang artinya bahwa responden yang memiliki kebiasaan menggantung pakaian pada kelompok menderita 0,252 kali lebih beresiko menderita DBD dibandingkan dengan responden yang tidak memiliki kebiasaan menggantung pakian.

Hasil penelitian ini sejalan dengan hasil penelitian Rahmadani, (2016) di Wilayah Kerja Puskesmas Purwokerto Selatan Kabupaten Banyumas Tahun 2016 yang menemukan ada hubungan yang bermakna antara kebiasaan menggantung pakaian dengan kejadian DBD. Menurut Isnawanty kunji (2013) hal ini merupakan faktor yang berpengaruh terhadap penyakit DBD, karena salah satu tempat kebiasaan nyamuk istirahat itu ada pada pakaian yang bergantungan.

Hasil penelitian ini juga diperkuat dengan hasil penelitian Elvin (2016) yang mengenai faktorfaktor yang berhubungan dengan kejadian DBD. Hasil penelitian tersebut dari hasil uji statistik chisquare menunjukan bahwa $p$-value 0,021 yang berarti ada hubungan yang signifikan antara kebiasaan menggantung pakaian dengan kejadian DBD.

Sedangkan hasil penelitian ini berbeda dengan hasil penelitian Malau, Nurjazuli, dan Setiani, (2015) mengenai hubungan faktor lingkungan dan perilaku keluarga dalam pencegahan dengan kejadian demam berdarah dengue. Dari hasil uji statistik dengan menggunakan Chi-square, diperoleh $p$-value 0,491 karena $p$-value $>0,05$ maka Ho diterima, artinya tidak ada hubungan yang bermakna antara variabel penggantungan pakaian dengan kejadian Demam Berdarah Dengue di wilayah kerja Puskesmas Kedungmundu Kecamatan Tembalang Kota Semarang tahun 2014.

\section{Hubungan keberadaan barang bekas disekitar rumah dengan kejadian DBD}

Menurut (Ferdiansyah 2016 dalam Sari, 2018), lingkungan yang menjadi habitat nyamuk Aedes aegypti adalah digenangan air bersih yang tidak berkontak langsung dengan tanah dan tidak terkena langsung dari sinar matahari. Ban, botol, plastik, dan barang-barang lain yang dapat menampung air merupakan sarana yang memungkinkan untuk tempat perkembangbiakan nyamuk.

Sebagian besar responden tidak memiliki kebiasaan menyingkirkan barang bekas dan membiarkan barang bekas tersebut berada diluar rumah dan ditempat terbuka. Sehingga barangbarang bekas tersebut dapat menampung air hujan dan menjadi tempat perkembangbiakan nyamuk. Dengan demikian, untuk mencegah perkembangbiakan nyamuk, sebaiknya barangbarang bekas tersebut disingkirkan dan diletakan diruang tertutup agar tidak dapat menampung air hujan (Depkes, RI 2010 dalam Ayun, 2017).

Hasil uji statistik dengan Fisher's Exact Test di peroleh nilai $p$-value $0,256>\alpha=0.05$ artinya bahwa tidak ada hubungan antara keberadaan barang bekas di sekitar rumah dengan kejadian DBD di Wilayah Kerja Puskesm Mamajang. Berdasarkan nilai OR sebesar 0,234 yang artinya bahwa responden yang di sekitar rumah tidak terdapat barang bekas pada kelompok tidak menderita 0,234 kali lebih beresiko menderita DBD dibandingkan dengan responden yang sekitar rumah terdapat barang bekas.

Hasil peneltian ini berbeda dengan hasil penelitian sari (2018) mengenai hubungan faktor lingkungan dan prilaku dengan kejadian DBD yang menyatakan ada hubungan yang bermakna antara kebiasaan menyingkirkan barang-barang bekas dengan kejadian DBD di wilaya kerja puskesmas klagnserut. Hal ini menunjukkan bahwa kondisi lingkungan yang buruk dan masih terdapat 
genangan air serta dengan keberadaan barang bekas diluar rumah akan menjadi faktor penyebaran DBD karena dapat memicu bersarangnya nyamuk Aedes.

Sedangkan hasil penelitian ini juga berbeda dengan hasil penelitian Ayun, Pawenang (2017) mengenai hubungan antara faktor lingkungan dan prilaku dengan kejadian DBD yang menyatakan ada hubungan yang bermakna kebiasaan menyingkirkan barang-barang bekas dengan kejadian DBD di wilaya kerja puskesmas Sekaran dengan $p$-value $=0,026$.

\section{KESIMPULAN DAN SARAN}

Berdasarkan hasil penelitian di Wilayah Kerja Puskesmas Mamajang Kota Makassar dan dilakukan analisis data menggunakan uji chissquare dan uji Fisher's Exact Test maka diperoleh kesimpulannya adalah ada hubungan antara penggunaan kelambu ( $p=0,032 ; \mathrm{OR}=5,000)$, penggunaan kawat kasa ( $p=0,010 ; \mathrm{OR}=0,265)$, kebiasaan menggantung pakaian $(p=0,008$; $\mathrm{OR}=0,252$ ) dengan kejadian $\mathrm{DBD}$, dan tidak ada hubungan keberadaan barang bekas $(p=0,256)$ dengan kejadian DBD di wilayah kerja Puskesmas Mamajang Kota Makassar.

Peneliti menyarankan kepada Petugas Puskesmas Mamajang agar dapat meningkatkan program kesehatan lingkungan dan program pemberantasan sarang nyamuk (PSN) di wilayah kerja Puskesmas Mamajang Kota Makassar sehingga dapat menurunkan angka kejadian DBD, Gerakan PSN oleh masyarakat agar lebih ditingkatkan lagi dengan membersihkan lingkungan sekitar guna memutus rantai penularan DBD.

\section{DAFTAR PUSTAKA}

Abbas, syafar M dan Arsin A, (2010). Faktor yang berhubungan dengan kejadian penyakit demam berdarah dengue (DBD) di kabupaten jeneponto. Jurnal MKMI, 6(2), hal. 65-70.
Astuti L, (2018). Hubungan kondisi lingkungan fisik terhadap tingkat kepadatan larva Aedes $s p$ di sekolah dasar wilayah kecamatan kasihan, bantul, di yogyakarta. ISSN Vol 216225 hal (3-9)

Ayun, Pawenang, (2017). Hubungan antara faktor lingkungan fisik dan prilaku dengan kejadian demam berdarah dengue (DBD) di Wilayah Puskesmas Sekaran, Kecamatan Gunungpati, Kota Semarang. UNNES hal. 97-104.

Bakrie, (2019). 8 orang meninggal dunia, Sulses waspada DBD. Maros. Makassar. (online). https://news.detik.com/berita/d-

4410510/8-orang-meninggal-dunia-sulsel waspada-dbd [diakses,23 mei 2020).

Cinesa, K Gaudensius, (2016). Faktor yang berhubungan dengan kejadan DBD di wilayah Puskesmas Elar Kecamatan Elar Kabupaten Manggarai Timur. Skripsi. Fakultas Kesehatan Masyarakat Universitas Pancasakti Makassar.

Kamaluddin, (2019). Gambaran peran serta masyarakat dalam pengendalian vektor demam derdarah berdasarkan angka bebas jentik di Kelurahan Sudiang Raya Kecamatan Biringkanaya Kota Makassar. skripsi. Fakultas kedokteran dan ilmuh kesehatan universitasislam negeri uin alauddin.

Nur NH \& Lestin D, (2019). Faktor Yang Berhubungan Dengan Kejadian Malaria Di Wilayah Kerja Puskesmas Loce Kabupaten Manggarai, Jurnal Promotif Preventif, 2(1), 36-43

Nur NH \& Mira M, (2020). Faktor-faktor Yang Berhubungan Dengan Kejadian Malaria di Wilayah Kerja Puskesmas Wandai Distrik Wandai Kabupaten Intan Jaya Papua, Jurnal Promotif Preventif, 2(2), 1-7

Rahmadani, Anwar, Hari Rudijanto, (2016). Faktor risiko lingkungan dan perilaku yang berhubungan Dengan kejadian penyakit demam berdarah dengue (DBD) Di Wilayah Kerja Puskesmas Purwokerto Selatan Kabupaten Banyumas.Jurusan Kesehatan Lingkungan. 
Ramawati D.R, Nurjazuli, Dangiran L.H, (2016). Hubungan Kondisi Lingkungan Fisik, Biologis Dan Praktis Pemberantasan Sarang Nyamuk (PSN) Dengan Kejadian DBD Diwilaya Kerja Puskesmas Ngawi, Kec. Ngawi, Kab. Ngawi. Ngawi. Fakultas Kesehatan Masyarakat Universitas Diponegoro. Jurnal kesehatan masyarakat.

Sari E.D, (2019). Pengetahuan, sikap dan pendidikan dengan pencegahan demam berdarah dengue menggunakan prinsip menguras, menutup dan memanfatkan kembali. Palembang. Jurnal IImiah STIKES Citra Delima Bangka Belitung. Vol.3 No.2: $163-170$.

Sari P.W.U, (2018). Hubungan Faktor Lingkungan Dan Prilaku Dengan Kejadian DBD di Wilaya Kerja Puskesmas Klagenserut. Skripsi. STIKES Bhakti Husada Mulia Madiun.

Sunarya, (2019). Hubungan Sanitasi Lingkungan Kejadian Penyakit DBD Di Wilayah Kerja Puskesmas Sentosa Baru Kecamatan Medan Perjuangan Kota Medan Tahun 2019.
Skripsi. Universitas Islam Negeri Sumatra Utara.

Tamza S, Dharminto, (2013). Hubungan faktor lingkungan dan perilaku dengan kejadian demam berdarah dengue (DBD) di wilayah kelurahan perumnas way halim Kota Bandar Lampung. JKM Vol.2 No.2.

Utomo, (2017). Hubungan antara perilaku pemberantasan sarang nyamuk dan kejadian demam berdarah dengue di Desa Sojomerto Kecamatan Reban Kabupaten Batang. Skripsi. Fakultas Kedokteran Universitas Diponegoro, Semarang.

Wijirahayu S, Sukesi W.T, (2019). Hubungan Kondisi Lingkungan Fisik dengan Kejadian Demam Berdarah Dengue di Wilayah Kerja Puskesmas Kalasan Kabupaten Sleman. JKLI.vol. 18 halaman 1412-4939.

Yunita, M.S, (2012). Pengaruh Perilaku Masyarakat dan Kondisi Lingkungan Terhadap Kejadian Demam Berdarah Dengue. 